\title{
The study of the stress-strain state of the massif in mining uranium at "VOSTGOK" deposits
}

\author{
Mykola Stupnik, Vsevolod Kalinichenko, Mykhailo Fedko, Olena Kalinichenko, and Mykhailo Hryshchenko*
}

Kryvyi Rih National University, Department of Underground Mining of Mineral Deposit, 11 Vitalii Matusevych Str., Kryvyi Rih, 50027, Ukraine

\begin{abstract}
Being one of the world's largest uranium producers(about $2 \%$ of the world's production), the state enterprise "Vostochnyi Mining and Processing Works" ("VostGOK") provides about 40\% of Ukraine's nuclear power stations with uranium raw materials. Considering the conditions of uranium deposits exploitation (location in densely populated areas, protected sites etc.), to protect the environment from possible emissions of radioactive elements room mining is applied with subsequent backfilling of the dead area with consolidating mixtures. This technology is economically reasonable at deposits with the increased uranium content. To exclude a number of labour-consuming and environmentally dangerous operations from the production process, lean uranium-containing ores are reasonable to be mined applying underground block leaching. This enables reaching maximum values of mineral extraction and avoiding considerable material expenditures on backfilling mixture preparation and backfilling dead rooms, as they are almost completely backfilled with the muck pile, and on utilization of waste after the mined ore primary processing (barren rocks and off-balance ores) on the daylight surface.
\end{abstract}

\section{Introduction}

Further cut of costs can also be achieved through mining deposits by vertical double blocks. Ore body 10 of the Michurinskoye deposit is supposed to be mined in blocks 10-2 and 10-3 at the 325-184 m level at the Ingulskaya mine (Fig.1).

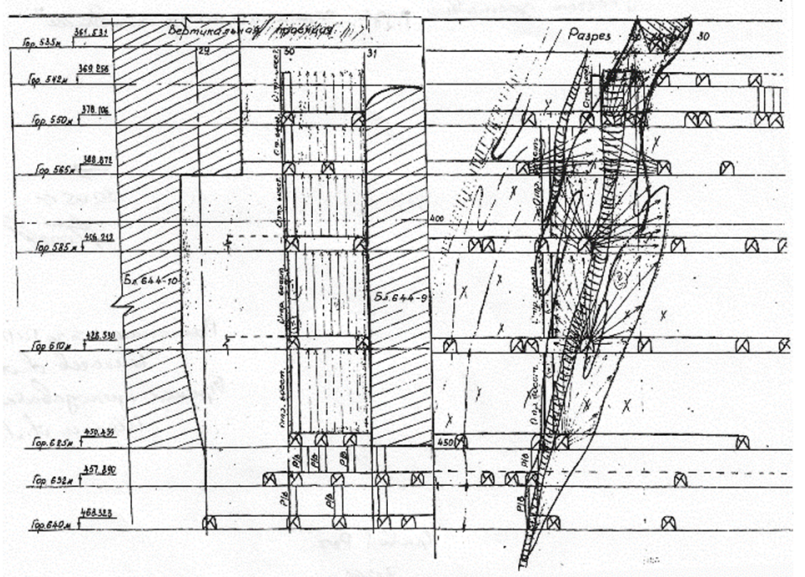

Fig. 1. The vertical plane of blocks 10-2 and 10-3 (ore body 10 of the Michurinskoye deposit).

The process is as follows. Another room is located under the temporary pillar-crown below the dead room backfilled with the muck pile. Under this pillar in the block located further down the dip angle compensatory room is placed to which reserves of this block are broken and the temporary crown is brought down. The solution for leaching uranium ores is fed from the existing workings over the room of the upper block. At this, volumes of mining are cut and pipes are again used for feeding the working solution to blocks [1-3].

The levels of stress in main structural units and in the enclosing rock massif, the condition of the roof bar (the degree of its disturbance caused by workings and deep shafts) are different from those occurring when the traditional technology is applied. Besides, the crown is affected by reagents for underground block leaching. Due to all that, factors impacting the crowns stability and mine safety on the whole require urgent investigations.

Determining permissible dimensions of main structural element of room mining systems [main regulatory documents $[1,2]$ however, do not consider the influence of the ore bed dip and are not intended for determining the safe thickness of a roof. The technology of underground block leaching of uranium ores in vertical double blocks is a new one to be applied at VostGOK underground mines and requires scientific support [4-7].

To study the stress-strain state and stability of crowns depending on the dip of ore bed and the conditions of the above mentioned blocks, mathematical modelling applying the finite-element technique was applied. The range of boundary conditions of the impacting factors included values characteristic of all the underground mines of "VostGOK". Uranium ore hardness varied from 9-11 to 14-16 on the Protodyakonov scale, that of the enclosing rock - 13-15, the dip of ore body made from $60^{\circ}$

\footnotetext{
* Corresponding author: Michael.grischenko@gmail.com
} 
to $90^{\circ}$ (in increments of $10^{\circ}$ ). The stress-strain state was calculated for roofs of 10 to $14 \mathrm{~m}$ thick. For calculating the stress field characteristics ANSYS 18 was used [8-10].

The results of modelling the stress-strain state of $10 \mathrm{~m}$ thick roofs in ores of various hardness with the ore body dip angles of $90^{\circ}, 70^{\circ}$ and $60^{\circ}$ are presented in Fig 2, 3 and 4 [11].

\section{Methods}

As is seen, the tension stress zone in the lower central part of the crown is the most dangerous. This corresponds to the classical concepts of stress field development in the so called "stress relief arch" that occurs when the massif is undermined by the lower block room. As ore hardness reduces, absolute values of stress in the crown decrease slightly (by $0.1 \ldots 0.5 \mathrm{MPa}$, i.e. from $1 \ldots .2$ to $6 \ldots 7 \%$ ). This can be explained by the fact that less hard ores are less liable to accumulate stress as they get relieved through deforming towards a post mining voids (i.e. the room) and, on the opposite, harder ores tend to accumulate stress due to smaller deformations. However, stability of less hard ore crowns decreases due to reduction of their ultimate strength [12-14].

For instance, with the ore body dip angle $\alpha=90^{\circ}$ and hardness of 14-16, the value of tensile stress in the lower part of the crown reaches $10.1 \mathrm{MPa}$ (Fig. 2, a). However, as ultimate tensile stress of such ores is about $11 \mathrm{MPa}$, these stresses will not cause failures.
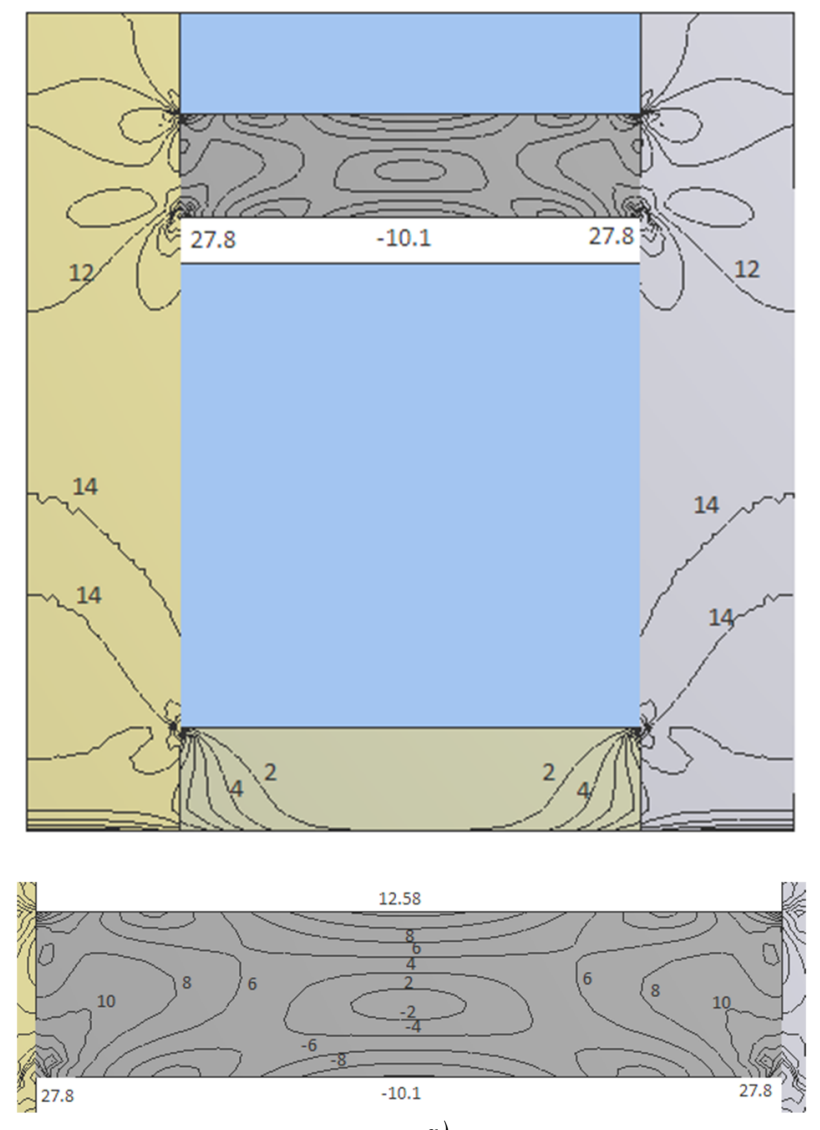

a)
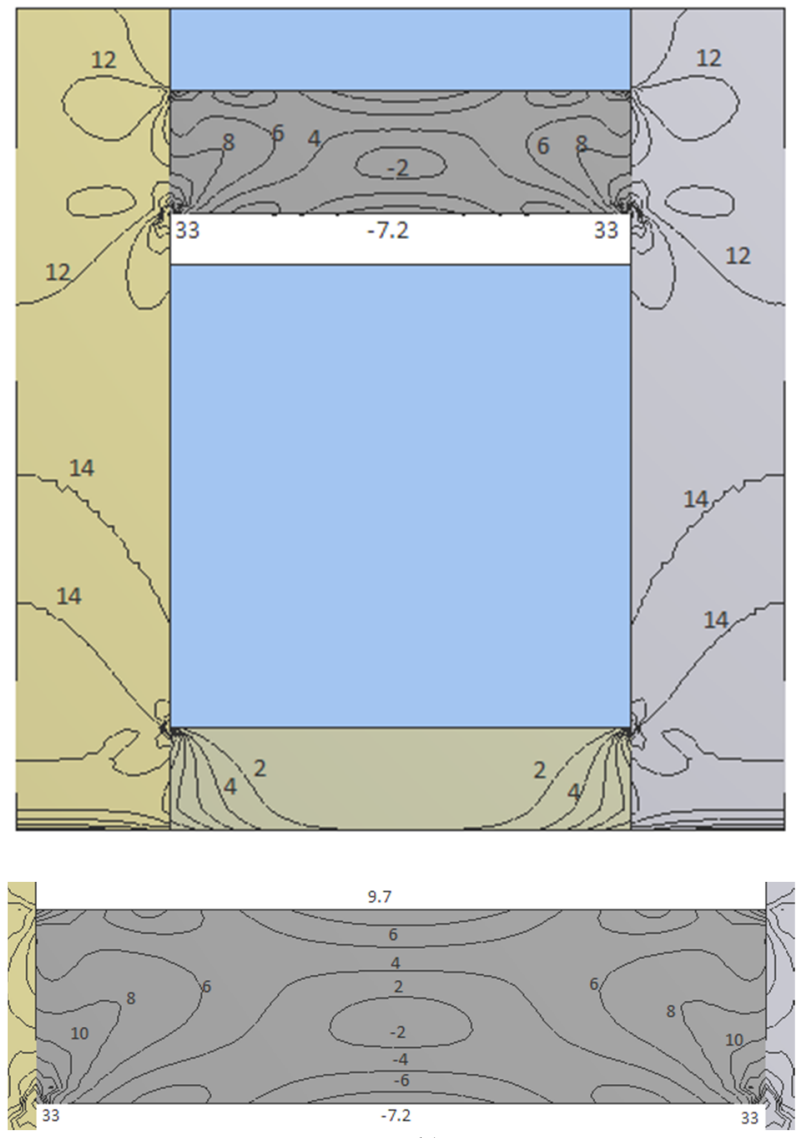

b)
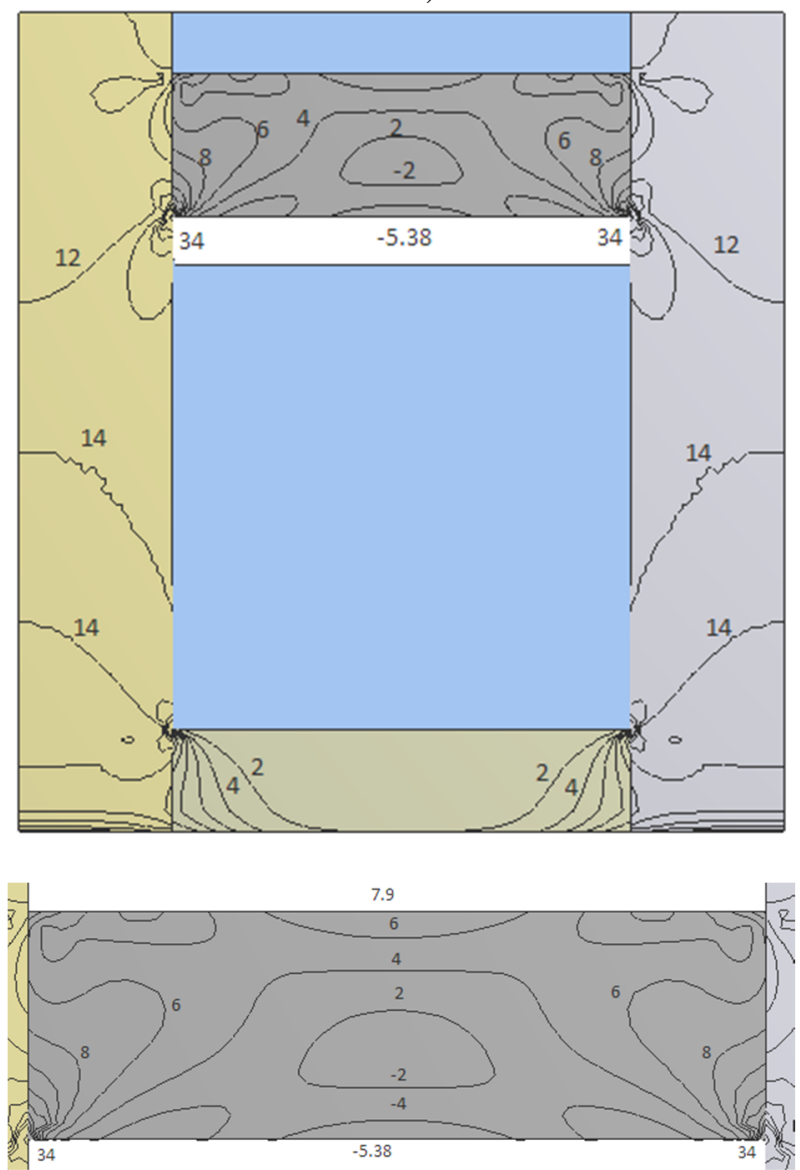

c)

Fig. 2. Stress field propagation in $10 \mathrm{~m}, 12 \mathrm{~m}, 14 \mathrm{~m}$ in roof layers with the ore body dip of $90^{\circ}, \mathrm{MPa}$. 
When the crown is made of ores of 10-11 points (Fig. 2,d), the tensile stress level makes 9.9 MPa. With the ultimate strength of the ores of $7.7 \mathrm{MPa}$ this will cause rock falls of about $100 \ldots 150 \mathrm{~m}^{3}$ (according to "Instructions..." [15] used at "VostGOK" mines, rock falls of over $250 \ldots 300 \mathrm{~m}^{3}$ are considered critical).

With the dip angle $\alpha=70^{\circ}$ and ores of 14-16 points roof failures do not practically occur (Fig. 3, a), with $\alpha=60^{\circ}$ small rock falls $\left(3-5 \mathrm{~m}^{3}\right)$ may occur even in crowns of ores of the same hardness (Fig. 4, a). In roofs of ores of 10-11 points with $\alpha=70^{\circ}$ (Fig. 3, b) and $\alpha=60^{\circ}$ (Fig. 4, b) the volume of rock falls will make from 150 to $200 \ldots 220 \mathrm{~m}^{3}$, sometimes to $400 \ldots 450 \mathrm{~m}^{3}$ respectively [16-18].
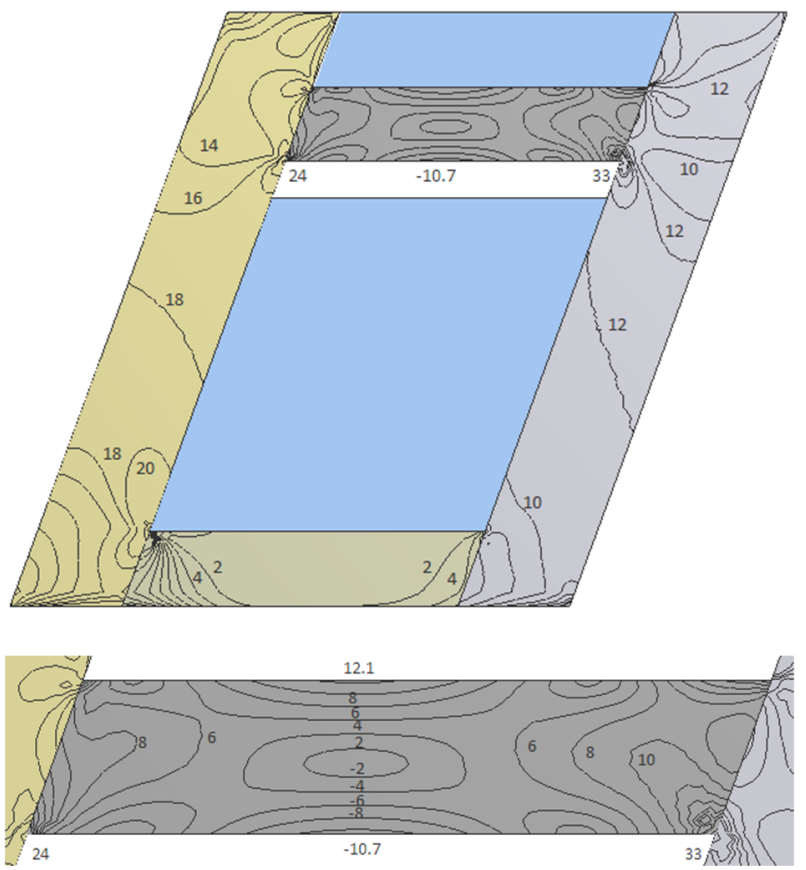

a)
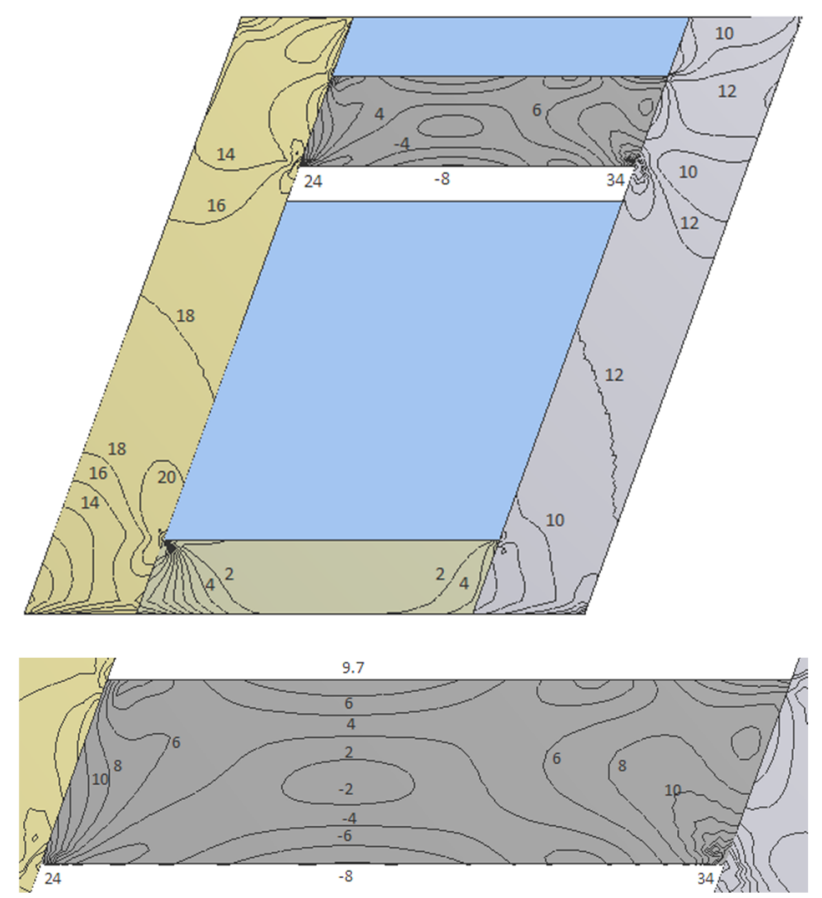

b)
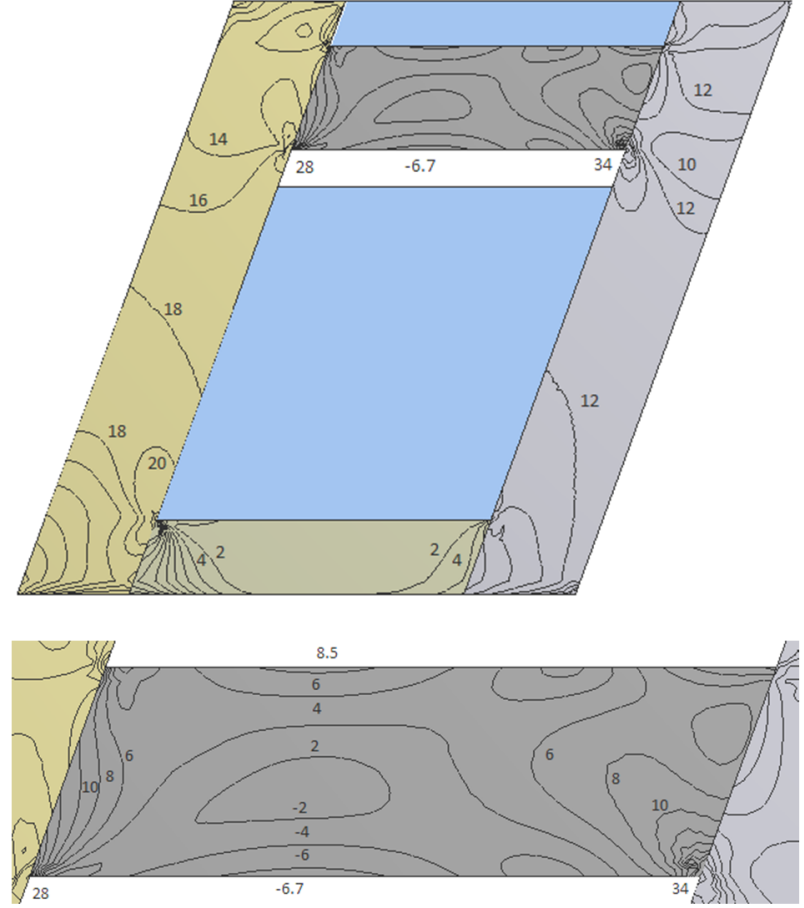

c)

Fig. 3. Stress field development in $10 \mathrm{~m}, 12 \mathrm{~m}, 14 \mathrm{~m}$ crowns with the ore body dip of $70^{\circ}, \mathrm{MPa}$.

These values testify to the critical condition of the crown at angles about $\alpha=70^{\circ}$, at about $\alpha=60^{\circ}$ the crown will fail.

Thus, the obtained results testify to the considerable impact of the ore body dip angle on the stress-strain state of crowns and their stability and enable us to suggest application of the correction factor $K_{\alpha}$, whose numerical values are given in Fig. 5. [19-22] So, when determining the minimum permissible thickness of the crown in certain conditions, its value obtained without this factor should be corrected through multiplying it by the corresponding value $K_{\alpha}$ [23-26].

Changes in the existing stress fields, increase of absolute values of current stresses caused by technological workings result in decrease of the crown stability.

Due to this, when determining safe dimensions of exposures and pillars, they should be corrected considering the accepted criteria. In the first case, the crown thickness is determined according to conditions of the room mining order in compliance with the instructions developed by NIGRI (Research Ore Mining Institute) [27]. In the second case, the correction factor is applied.

We suggest correcting thickness of the crown with workings using the expression

$$
h_{c r}{ }^{n}=h_{c r} \cdot K_{\text {dist }}, \mathrm{m} \text {; }
$$

where $h_{c r}$ is thickness of the monolith crown, $\mathrm{m}$; $K_{\text {dist }}$ is the factor considering disturbance of the crown resulted from mining, unit fraction [28-31].

As the disturbance degree of the crown depends on the number of workings in it, their geometrical dimensions and thickness of the crown itself, we suggest determining the numerical value of $K_{d i s t}$ as the product of separate 
universal factors [32-35]. Each of these factors differentially takes into account the impact of a particular working on the crown stress-strain state and, consequently, on its stability, as follows

$$
K_{\text {dist }}=K_{1} \cdot K_{2} \cdot \ldots \cdot K_{n} \text {, unit fraction; }
$$

where $K_{n}$ is the number of workings in the crown.

Numerical values of these factors calculated individually for each working can tentatively be determined as follows

$$
K_{i}=\sqrt{1+\left(h_{i}^{W} / h_{c r}\right)}, \text { unit fraction; }
$$

where $h^{w}{ }_{i}$ is the $i$-th working height (width), m.

For instance, according to the calculations, the minimum permissible thickness of the crown not disturbed by workings is $h_{c r}=10 \mathrm{~m}$. In case of workings of $2.5,3.0,3.5$ and $4.0 \mathrm{~m}$, the correction factors for each of them determined by (3) will equal 1.12, 1.14, 1.16 and 1.18 respectively.
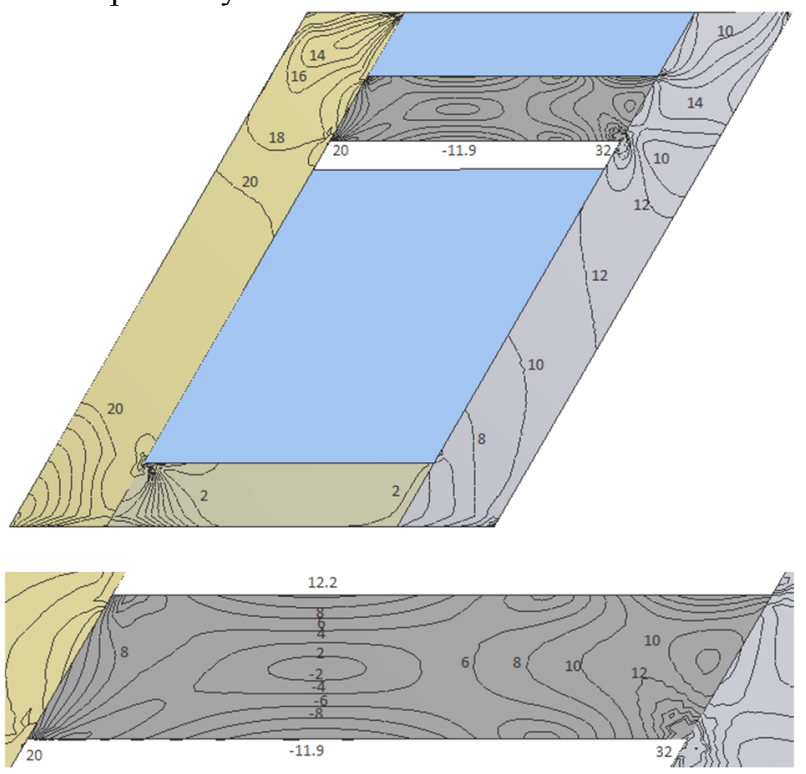

a)
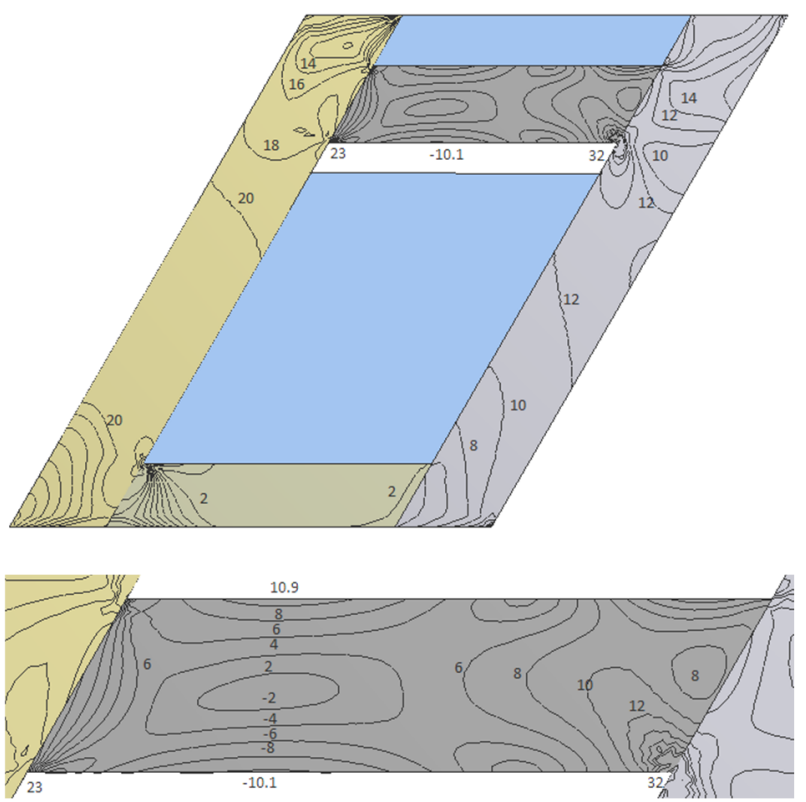

b)
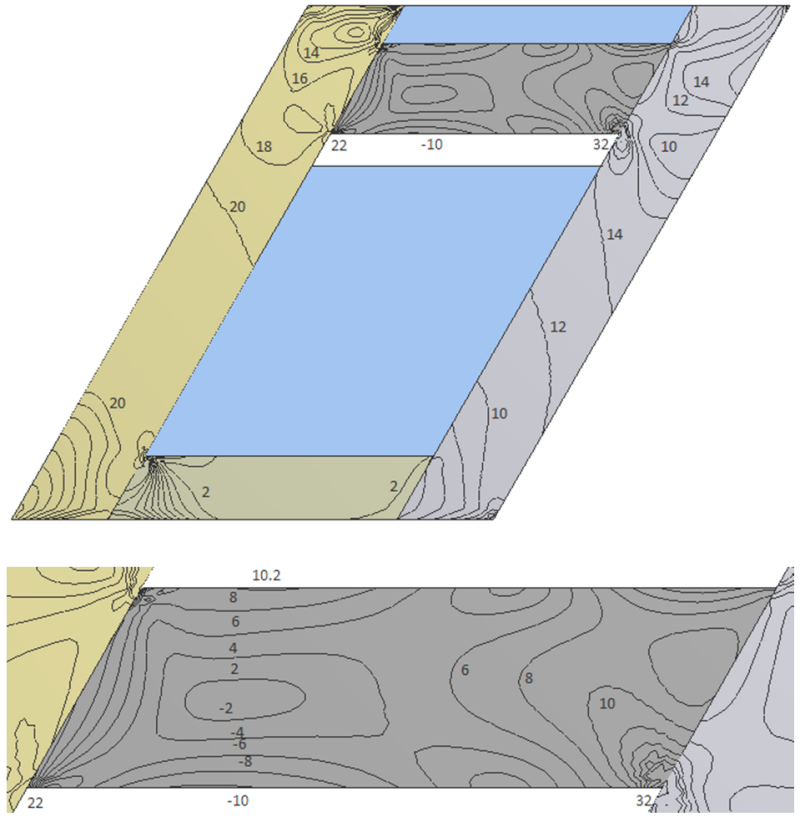

c)

Fig. 4. Stress field development in $10 \mathrm{~m}, 12 \mathrm{~m}, 14 \mathrm{~m}$ crowns with the ore body dip of $60^{\circ}, \mathrm{MPa}$.

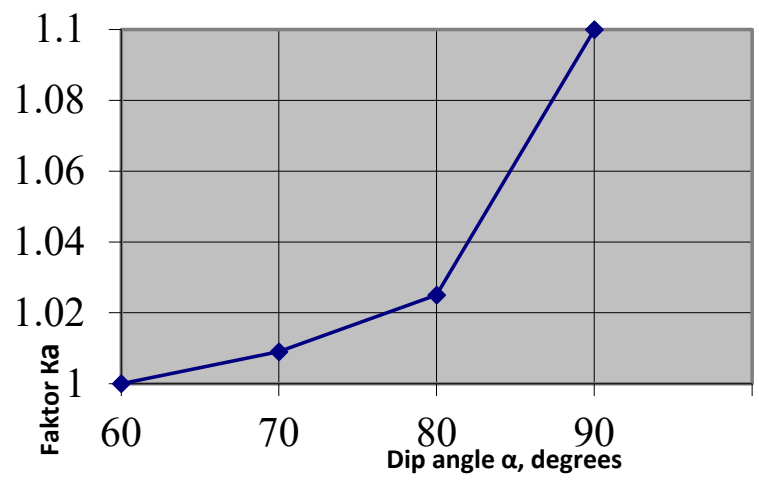

Fig. 5. $K_{\alpha}$ values depending on the ore body dip angle $\alpha$.

Thus, the crown thickness should be increased to 11.2 , $11.4,11.6$ and $11.8 \mathrm{~m}$ respectively [36-39].

If there are 2 workings of $3.0 \mathrm{~m}$ and $3.5 \mathrm{~m}$ in the crown, the correction factor will make $K_{\text {dist }}=1.14 \cdot 1.16=1.32$. Correspondingly, the disturbed crown thickness should be increased to $13.2 \mathrm{~m}[40,41]$.

If there are 3 workings of $2.5 \mathrm{~m}, 3.0 \mathrm{~m}$ and $3.5 \mathrm{~m}$ in the crown, the correction factor will make $K_{\text {dist }}=1.12$. $1.14 \cdot 1.16=1.48$. Under such conditions the crown thickness should be half as much as that of the monolith crown and make $14.8 \mathrm{~m}$.

\section{Results and discussion}

So, the crown thickness should be corrected considering decrease of its stability caused by workings. This will help avoid its complete or partial failure.

As shrinkage stoping with sulphuric acid treatment is one of the main components of underground block leaching of uranium ores, the crown separating the rooms will also be exposed to the sulphuric acid. 
The research conducted enables the authors to assume that the longstanding (from 3-4 to 6 months) exposure to the sulphuric acid may negatively impact strength properties of the ore massif of the crown. This assumption is substantiated by data on the physical and mechanical properties of rocks of the Michurinskoye deposit, particularly albitites and migmatites which are the most representative rocks in uranium ore occurrence zones. Thus, the average compressive resistance of rocks in their natural humidity conditions and when water-saturated makes 164.4 MPa and 127.5 MPa for albitites and 153.1 and $112.4 \mathrm{MPa}$ for migmatites respectively. That is, if compared with the natural state, water saturation of rocks reduces their compressive resistance by $22 \ldots 27 \%$.

The analysis of the data on the physical and mechanical properties of rocks of the Michurinskoye deposit, particularly albitites and migmatites which are the most representative rocks in uranium ore occurrence zones, enables the authors to conclude that the longstanding (from 3-4 to 6 months) exposure to the sulphuric acid may negatively impact strength properties of the ore massif of the crown. The average compressive resistance of rocks in their natural humidity conditions and when water-saturated makes $164.4 \mathrm{MPa}$ and 127.5 $\mathrm{MPa}$ for albitites and 153.1 and 112.4 MPa for migmatites respectively. That is, if compared with the natural state, water saturation of rocks reduces their compressive resistance by $22 \ldots .27 \%$.

The impact of the sulphuric acid solution on the crown stability was confirmed by the following investigation. Forty ore cubes with $50 \mathrm{~mm}$ sides were divided into two groups. The first group of 10 cube shaped samples was used to determine the uniaxial compressive resistance in the natural conditions, the remaining cubes were used for determining the degree of the sulphuric acid solution impact on the samples' strength.

To provide conditions of the crown contacting the acid solution, in the laboratory environment only one face of an ore sample contacted the acid solution. The other faces of the cubes were covered with two coatings of paraffin. These cubes were placed in a vessel with the sulphuric acid solution which is used for spraying the shrinked muck pile in underground mines of "VostGOK". Tests of uniaxial compressive resistance were carried out 2.5, 4 and 6 months after dipping to determine the impact of the exposing time on the uranium ore strength. These periods correspond to the minimum and maximum time of the reagent impact in real conditions.

The laboratory hydraulic press is able to produce pressure up to $50 \mathrm{t}$. In relation to the cubes' surface $S=25 \mathrm{~cm}^{2}$ the corresponding pressure makes about 2000 $\mathrm{kg} / \mathrm{cm}^{2}$, or $200 \mathrm{MPa}$. The press is coupled with a computer that sets the loading rate for the samples and forms the loading diagram for each of the samples with the automatic recording of the current load, maximum pressure at the moment of their destruction and calculates ultimate strength of each sample depending on its sizes. During the tests the minimum loading rate of $1 \mathrm{kN} / \mathrm{s}$ was set according to corresponding standards (from 1 to $5 \mathrm{kN} / \mathrm{s}$ ).

The samples of the first group demonstrated the average value of the uniaxial compressive resistance of about $130 \mathrm{MPa}$. According to the instructions [42] this value corresponds to the rock hardness ratio of 11 points. For the samples exposed to the sulphuric acid solution during 2.5, 4 and 6 months, average strength values made $82 \ldots 84.5,79.5 \ldots 80.5$ and about $78 \mathrm{MPa}$ respectively, i.e. their ultimate strength decrease (in relation to the samples of the first group) made $35 \ldots 37 \%, 38 \ldots 39 \%$ and about $40 \%$.

\section{Conclusions}

Thus, the tests conducted confirmed the authors' assumption about the considerable impact of the acid solution on the uranium ore strength and, consequently, the stability of exposures and pillars. The determined dependencies should be considered in defining the safe crown thickness when applying the technology of underground block leaching of uranium ores.

So, the research conducted enabled determining the degree of impact of major factors (ore body dip, crown integrity loss caused by technological workings, impacts of reagent used when applying underground block leaching of uranium ores) on the crown stability. These factors should be taken into account when determining safe dimensions of exposures and pillars using corresponding correction factors. As a result, in concrete conditions it is necessary to correct parameters of structural units of blocks, particularly the crown thickness, considering the value of its stability changes caused by the above factors. This correction enables avoiding the crown failure and provides safety of works. The determined dependencies can then be corrected considering practical experience of "VostGOK" underground mines.

So, the research conducted has resulted in the following:

- the degree of impact of major factors (ore body dip, crown integrity loss caused by technological workings, impacts of reagent used when applying underground block leaching of uranium ores) on the crown stability has been determined;

- the factors should be taken into account when determining safe dimensions of exposures and pillars using corresponding correction factors.

- in concrete conditions it is necessary to correct parameters of structural units of blocks, particularly the crown thickness, considering the value of its stability changes caused by the above factors. This correction enables avoiding the crown failure and provides safety of works.

The determined dependencies can then be corrected considering practical experience of "VostGOK" underground mines.

\section{References}

1. M. Stupnik, V. Kalinichenko, S. Pysmennyi, O. Kalinichenko, Naukovyi Visnyk Natsionalnoho Hirnychoho Universytetu 4, 21-27 (2018). doi:10.29202/nvngu/2018-4/4 
2. V. Kalinichenko, S. Pysmennyi, N. Shvaher, O. Kalinichenko, E3S Web of Conferences 60, 00041 (2018). doi:10.1051/e3sconf/20186000041

3. M.I. Stupnik, V.O. Kalinichenko, O.V. Kalinichenko, I.O. Muzika, M.B. Fed'ko, S.V. Pismennyi, Metallurgical and mining industry 7, 377383 (2015)

4. M. Stupnik, V. Kolosov, V. Kalinichenko, S. Pismennyi, Progressive Technologies of Coal, Coalbed Methane, and Ores Mining 25-30 (2014). doi:10.1201/b17547

5. O. Khomenko, A. Sudakov, Z. Malanchuk, Ye. Malanchuk, Naukovyi Visnyk Natsionalnoho Hirnychoho Universytetu 2, 35-43 (2017)

6. O. Khomenko, M. Kononenko, M. Petlyovanyy, in New Developments in Mining Engineering (2014), pp. 241-245 (2014)

7. O. Khomenko, M. Kononenko, M. Petlovanyi, in New Developments in Mining Engineering (2015), pp. 265-269

8. O. Khomenko, M. Kononenko, I. Kovalenko, D. Astafiev, E3S Web of Conferences 60, (2018). doi:10.1051/e3sconf/20186000009

9. M. Petlovanyi, V. Lozynskyi, P. Saik, K. Sai, E3S Web of Conferences 123, (2019). doi:10.1051/e3sconf/201912301019

10. M. Petlovanyi, V. Lozynskyi, S. Zubko, P. Saik, K. Sai, Rudarsko Geolosko Naftni Zbornik 34/1, 83-91 (2019). doi:10.17794/rgn.2019.1.8

11. Z.R. Malanchuk, V.S. Moshynskyi, V.Ya. Korniienko, Ye.Z. Malanchuk, V.H. Lozynskyi, Naukovyi Visnyk Natsionalnoho Hirnychoho Universytetu 6, 22-28 (2019). doi:10.29202/nvngu/2019-6/2

12. V. Lozynskyi, P. Saik, M. Petlovanyi, K. Sai, Z. Malanchuk, International Journal of Engineering Research in Africa. 35, 77-88 (2018). doi:10.4028/www.scientific.net/jera.35.77

13. M. Petlovanyi, O. Kuzmenko, V. Lozynskyi, V. Popovych, K. Sai, P. Saik, Mining of Mineral Deposits 13/1, 24-38 (2019). doi:10.33271/mining13.01.024

14. N. Morkun, T. Oliinyk, I. Kasatkina, O. Rytsko, E3S Web of Conferences $\mathbf{1 2 3}$ (2019). doi:10.1051/e3sconf/201912301038

15. Instruktsia po obosnovaniyu bezopasnykh I ustoichivykh parametrov ochistnykh blokov na shakhtakh GP "VostGOK" (Instructions for substantiating safe and stable parameters of stopes at underground mines of SE "VostGOK"). (GP "UkrNIPIIpromtekhnologii", Zheltye Vody)

16. V. Serhiienko, E3S Web of Conferences 109, 00084 (2019). doi:10.1051/e3sconf/201910900084

17. V. Tron, O. Tsokurenko, D. Paraniuk, I. Haponenko, E3S Web of Conferences 123, 01037 (2019). doi:10.1051/e3sconf/201912301037
18. D.V. Brovko, V.V. Khvorost, V.Yu. Tyshchenko, Naukovyi Visnyk Natsionalnoho Hirnychoho Universytetu 4, 66-71 (2018). doi:10.29202/nvngu/2018-4/14

19. V. Morkun, N. Morkun, A. Pikilnyak, Metallurgical and Mining Industry 6/2, 36-42 (2014)

20. V. Morkun, N. Morkun, A. Pikilnyak, Metallurgical and Mining Industry 6/2, 43-48 (2014)

21. V. Golik, V. Komashchenko, V. Morkun, Metallurgical and Mining Industry 7/4, 321-324 (2015)

22. V. Golik, V. Komashchenko, V. Morkun, O. Burdzieva, Metallurgical and Mining Industry 7/6, 591-594 (2015)

23. V. Morkun, N. Morkun, V. Tron, Metallurgical and Mining Industry 7/8, 18-21 (2015)

24. V. Morkun, N. Morkun, V. Tron, Metallurgical and Mining Industry 7/10, 6-9 (2015)

25. V. Morkun, N. Morkun, V. Tron, S. Hryshchenko, O. Serdiuk, I. Dotsenko, Archives of Acoustics 44/1, 161-167 (2019)

26. A. Kupin, D. Kuznetsov, I. Muzyka, O. Suvorov, V Dvornikov, Eastern-European Journal of Enterprise Technologies 4/2 (94), 71-79 (2018)

27. V. Tron, O. Tsokurenko, D. Paraniuk, I. Haponenko, E3S Web of Conferences 123 (2019) doi:10.1051/e3sconf/201912310037

28. Ye.K. Babets et al. Opredelenie I control dopustimykh razmerov konstructivnykh elementov system razrabotki zheleznykh rud. Instruktsia po primeneniyu (Determination and control of permissible dimensions of structural units of iron ore mining systems. Instructions for use). (GP "NIGRI", Krivoy Rog, 2010)

29. K. Rysbekov, D. Huayang, T. Kalybekov, M. Sandybekov, K. Idrissov, Y. Zhakypbek, G. Bakhmagambetova, Mining of Mineral Deposits 13/3, 40-48 (2019). doi:10.33271/mining13.03.040

30. T. Kalybekov, M. Sandibekov, K. Rysbekov, Y. Zhakypbek, E3S Web of Conferences 123, 01004 (2019). doi:10.1051/e3sconf/201912301004

31. S. Pysmennyi, D. Brovko, N. Shwager, I. Kasatkina, D. Paraniuk, O. Serdiuk, Eastern-European Journal of Enterprise Technologies 5/1 (95), 33-45 (2018). doi:10.15587/1729-4061.2018.142483

32. S. Dineva, M. Boskovi, Evolution of seismicity at Kiruna Mine, in Proceedings of the Eighth International Conference on Deep and High Stress Mining, ed, by J. Wesseloo (Australian Centre for Geomechanics, 2017), pp. 125-139

33. Y. Biruk, H. Mwagalanyi, Master's thesis. Department of Civil, Environmental and Natural Resources Engineering 74 (2010)

34. B.M. Andreev, D.V. Brovko, V.V. Khvorost, Metallurgical and mining industry 12, 378-382 (2015) 
35. V. Dengub, V. Shapovalov, M. Hudyk, Metallurgical and Mining Industry 5, 67-71 (2015)

36. R. Dychkovskyi, V. Lozynskyi, P. Saik, M. Petlovanyi, Y. Malanchuk, Z. Malanchuk, Archives of Civil and Mechanical Engineering 18/4, 11831197 (2018). doi:10.1016/j.acme.2018.01.012

37. N. Shvaher, T. Komisarenko, S. Chukharev, S. Panova, E3S Web of Conferences, 123, (2019) doi:10.1051/e3sconf/201912301043

38. B.I. Rymarchuk, O.L. Shepel, M.V. Khudyk, Naukovyi Visnyk Natsionalnoho Hirnychoho Universytetu, 3, 32-37 (2017)

39. O. Lapshyn, V. Shapovalov, M. Khudyk, O. Shepel, (2018). Naukovyi Visnyk Natsionalnoho Hirnychoho Universytetu. 2, 101-106.

40. B. Rymarchuk, O. Shepel, M. Khudyk, Naukovyi Visnyk Natsionalnoho Hirnychoho Universytetu. 3, 32-37 (2017)

41. O. Lapshyn, V. Shapovalov, M. Khudyk, O. Shepel, Naukovyi Visnyk Natsionalnoho Hirnychoho Universytetu, 2, 101-106 (2018)

42. Instruktsia po opredeleniyu ustoichivosti gornykh porod pri provedenii gornykh vyrabotok v usloviyakh uranovykh mestorozhdeniy, razrabatyvayemykh GP "VostGOK" (Instructions for determining rock stability in mining uranium deposits). (NIGRI GUVZ KNU", Krivoy Rog) 